\title{
A Highly Packed Biofilm Reactor with Cycle Cleaning for the Efficient Treatment of Rural Wastewater
}

\author{
Yanan Luan*(D), Chen Qiu, Yaoxian Li, Weichang Kang, Jianhua Zhang, Zuliang Liao and Xuejun Bi \\ School of Environmental and Municipal Engineering, Qingdao University of Technology, Qingdao 266033, China; \\ 13656393156@163.com (C.Q.); 17667526080@163.com (Y.L.); kkk17863936303@163.com (W.K.); \\ 17801071914@163.com (J.Z.); liaozuliang@163.com (Z.L.); bixuejunqut@163.com (X.B.) \\ * Correspondence: yananluan1996@163.com
}

Citation: Luan, Y.; Qiu, C.; Li, Y.; Kang, W.; Zhang, J.; Liao, Z.; Bi, X. A Highly Packed Biofilm Reactor with Cycle Cleaning for the Efficient Treatment of Rural Wastewater. Water 2021, 13, 369. https://doi.org/ $10.3390 /$ w13030369

Academic Editor: Stefano Papirio

Received: 6 January 2021

Accepted: 28 January 2021

Published: 31 January 2021

Publisher's Note: MDPI stays neutral with regard to jurisdictional claims in published maps and institutional affiliations.

Copyright: (c) 2021 by the authors. Licensee MDPI, Basel, Switzerland. This article is an open access article distributed under the terms and conditions of the Creative Commons Attribution (CC BY) license (https:/ / creativecommons.org/licenses/by/ $4.0 /)$.

\begin{abstract}
Biological treatment processes perform satisfactory in wastewater treatment, but the relatively high cost and complicated maintenance limit its application in rural areas. In this study, a highly packed biofilm reactor (HPBR), with a $90 \%$ packing ratio of carriers in the bioreactor, was designed for rural wastewater treatment. The results showed that the removal rates for chemical oxygen demand (COD) and ammonia were $3.04 \pm 1.81 \mathrm{~kg} / \mathrm{m}^{3} / \mathrm{d}$ and $0.49 \pm 0.18 \mathrm{~kg} / \mathrm{m}^{3} / \mathrm{d}$, respectively. Besides, the removal efficiency of total inorganic nitrogen (TIN) was $35.4 \%$ by the HPBR. The removal capacity of the HPBR is higher than other reported systems with fewer operational costs and maintenance. High-throughput sequencing was applied to further investigate the kinetics and principals. Microorganisms capable of simultaneous nitrification-denitrification were found to be dominant species in the HPBR system, which indicated that the nitrogen removal in HPBR is governed by simultaneous nitrification-denitrification. These findings suggest that HPBR can be used as an efficient reactor for rural wastewater treatment, demonstrating its feasibility in real applications.
\end{abstract}

Keywords: highly packed biofilm reactor; cycle cleaning process; rural wastewater treatment; high nutrient removal loading; simultaneous nitrification-denitrification

\section{Introduction}

The discharge of untreated or barely treated wastewater into natural water bodies will lead to deterioration of the natural water environment, such as eutrophication $[1,2]$. Due to the rapid industrialization, the amount of wastewater increased dramatically in cities and the rural countryside of China, which has become one severe pollution problem in China [3,4]. In the past 20 years, China has made tremendous efforts in wastewater pollution control, which leads to satisfactory wastewater collection and purification coverage in urban areas [5,6]. However, there is a shortage of wastewater collection systems in most rural areas in China, where more than half of the rural wastewater is discharged into natural water bodies without treatment $[7,8]$. The untreated wastewater discharge can significantly deteriorate the aquatic ecosystem integrity in rural countryside. Hence, increasing wastewater purification facilities requires urgent actions in rural areas [9].

Many novel technologies have been developed and applied in the last decades to remove the pollutants properly from rural wastewater [10]. For example, as one of the typical wastewater treatment processes in rural areas of China, a primary settling tank in conjunction with activated sludge process was widely accepted for the effective removal of rural wastewater. This process can remove more than half of the influent chemical oxygen demand (COD) and ammonia, which ensured the water quality of the discharge. However, the operation and maintenance cost of this process is relatively unacceptably high in rural areas (0.80-1.30 $\mathrm{RMB} / \mathrm{m}^{3}$ wastewater). In addition, professional maintenance personnel were needed in the activated sludge process. According to the research published in 2014, only $6 \%$ of the rural wastewater treatment facilities were managed under trained staff [11]. The shortage of trained stuff led to a situation that many of the wastewater facilities in 
rural areas were abandoned due to inappropriate maintenance [12]. These disadvantages hindered the long-term operation of the activated sludge process in the rural countryside. Another widely proposed process for rural wastewater treatment is constructed wetland because it is facile and cost-effective in treating rural wastewater. Nevertheless, the nutrient removal capacity is not satisfying considering its large area demand. In comparison with the activated sludge process and wetland process, biofilm reactor has a better and stable removal performance [13]. However, the conventional biofilm reactor is designed for urban wastewater treatment $(\mathrm{COD}<50 \mathrm{mg} / \mathrm{L}$, total nitrogen $<15 \mathrm{mg} / \mathrm{L}$ ) and the removal capacity per volume of the biofilm reactor is limited due to its low carrier packing ratio, which is not suitable in rural wastewater treatment [6]. Hence, in this study, a modified biofilm reactor was designed as a decentralized, low-cost, low-maintenance, and efficient wastewater treatment facility to meet the current condition in the vast rural countryside of China [14].

To address the lack of wastewater treatment in rural areas due to financial shortage, previous studies have developed a highly packed biofilm reactor (HPBR), which can be used for low-cost and efficient wastewater treatment $[15,16]$. However, the effluent stability of the system was limited due to frequent biomass shedding by large aeration. Hence, in this study, the HPBR system was optimized by separating the system into an aeration section and a filtration section to avoid unstable effluent from aeration section. The aim of this study was to investigate the feasibility of the two-stage HPBR in the sufficient treatment of rural wastewater and provide a competitive and applicable technology for rural areas. HPBR was operated for over 130 days using domestic wastewater, and the overall nutrients removal performance was assessed. Moreover, the nutrients removal mechanism of HPBR was investigated and proposed by microbial community results. The results obtained in this research will enable the future application of HPBR in rural wastewater treatment.

\section{Materials and Methods}

\subsection{Experimental Setup}

The volume of the bioreactor (acrylic material) used in this study is $15 \mathrm{~L}$. The bioreactor was separated by clapboard into two identical sections namely, the aeration section (AS) and the filtration section (FS). The clapboard was not inserted to the bottom of the bioreactor to leave room for the water flow but separate the carriers. An air compressor was used for aeration and mixing in the AS. The high-density polyethylene (HDPE) suspended carriers (Qingdao Spring Water Treatment Co., Ltd., Qingdao, China) used in this study were taken from the aerobic tank (Licunhe Wastewater Treatment Plant (WWTP), Qingdao, China) and the packing ratio was $90 \%(v / v)$. The temperature was not controlled during the whole period, ranging from 10.1 to $28.9^{\circ} \mathrm{C}$.

\subsection{Bioreactor Operation}

The bioreactor was started up with domestic wastewater using the effluent of primary settling tank in Licunhe WWTP under continuous mode (Figure 1a). At the first stage, the hydraulic retention time (HRT) of the whole empty bed was set at $3 \mathrm{~h}$ and the HRT of AS and FS are $1.5 \mathrm{~h}$. After day 15, a rainy season came, causing a lower concentration of pollutants in influents. The empty bed HRT was adjusted to 1 and $2 \mathrm{~h}$ to couple with the continuous rainy weather, however the nitrification-denitrification process was compromised due to the short retention time, resulting in ammonia and total inorganic nitrogen (TIN) concentration of the effluent fluctuated in a wide range. To enhance the $\mathrm{N}$ removal performance, the HRT was controlled at $3 \mathrm{~h}$ again after day 56 . The cycle cleaning process was conducted daily in the bioreactor (Figure 1b). During cycle cleaning process, the bioreactor was filled up with $7.5 \mathrm{~L}$ wastewater to make sure that the carriers can be fluidized (the packing ratio was $60 \%(v / v)$ under cycle cleaning model), the clapboard was lifted by $10 \mathrm{~cm}$, and the aeration quantity was increased to force the carriers to circulate from AS to FS in the bioreactor, thereby shearing biofilm in AS and washing the sludge in 
FS. The cycle cleaning process was maintained for one hour, after that, the bioreactor was adjusted to normal operation mode by discharging the excess water.

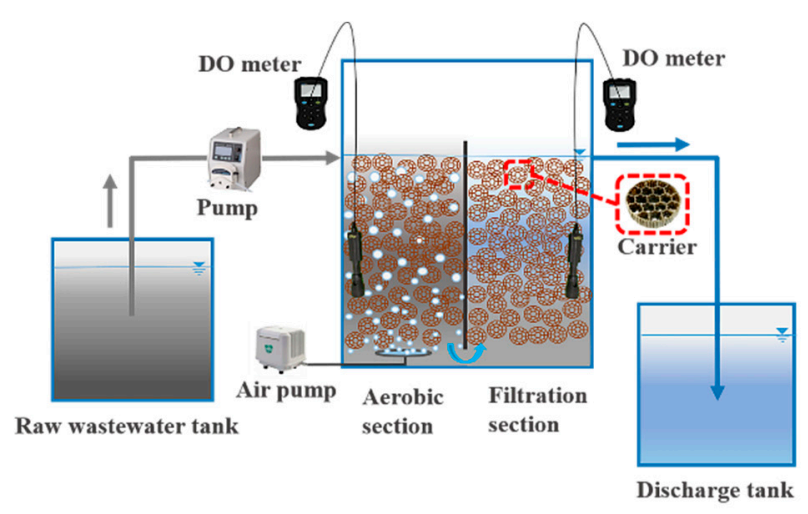

(a) Normal operation

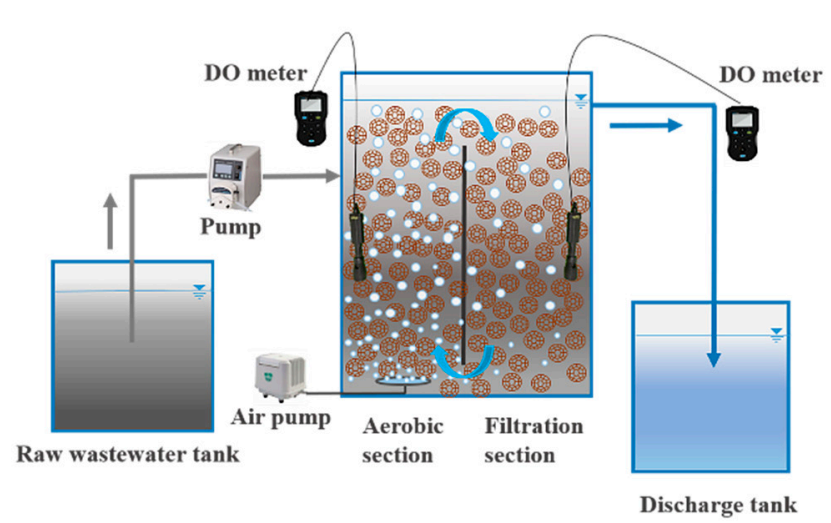

(b) Cycle cleaning process

Figure 1. Schematic diagram of the highly packed biofilm reactor (HPBR) under (a) normal operation and (b) cycle cleaning process.

\subsection{Wastewater Characteristics}

The wastewater was taken from Licunhe WWTP, Qingdao after the primary settling tank and stored in a collection tank before feeding into the bioreactor. The concentrations of COD, ammonia, and total suspended solids (TSS) were $231.5 \pm 94.8 \mathrm{mg} / \mathrm{L}$, $40.3 \pm 13.1 \mathrm{mg} / \mathrm{L}$, and $167.8 \pm 83.5 \mathrm{mg} / \mathrm{L}$, respectively. Other chemical characteristics are given in Table 1.

Table 1. Water quality characteristics of the original wastewater.

\begin{tabular}{ccc}
\hline \multirow{2}{*}{ Parameter } & \multicolumn{2}{c}{ Value } \\
\cline { 2 - 3 } & Average & Range \\
\hline Temperature $\left({ }^{\circ} \mathrm{C}\right)$ & $20.6 \pm 4.9$ & $10.1-28.9$ \\
DO $_{\mathrm{AS}}(\mathrm{mg} / \mathrm{L})$ & $6.7 \pm 1.2$ & $3.0-8.9$ \\
$\mathrm{DO}_{\mathrm{FS}}(\mathrm{mg} / \mathrm{L})$ & $2.3 \pm 1.0$ & $0.5-4.2$ \\
$\mathrm{pH}$ & $7.9 \pm 0.2$ & $7.5-8.2$ \\
$\mathrm{COD}(\mathrm{mg} / \mathrm{L})$ & $231.5 \pm 94.8$ & $98.6-603.0$ \\
SCOD $(\mathrm{mg} / \mathrm{L})$ & $151.7 \pm 60.1$ & $29.1-335.5$ \\
Ammonia $(\mathrm{mg} / \mathrm{L})$ & $40.3 \pm 13.1$ & $7.3-66.4$ \\
Nitrite $(\mathrm{mg} / \mathrm{L})$ & $0.1 \pm 0.2$ & $0-1.2$ \\
Nitrate $(\mathrm{mg} / \mathrm{L})$ & $1.2 \pm 1.2$ & $0-7.4$ \\
TIN $(\mathrm{mg} / \mathrm{L})$ & $41.7 \pm 13.0$ & $8.9-68.4$ \\
TSS $(\mathrm{mg} / \mathrm{L})$ & $167.8 \pm 83.5$ & $50-433$ \\
\hline
\end{tabular}

$\mathrm{DO}_{\mathrm{AS}}$ : dissolved oxygen in aeration section; $\mathrm{DO}_{\mathrm{FS}}$ : dissolved oxygen in filtration section; COD: chemical oxygen demand; SCOD: soluble chemical oxygen demand; TIN: total inorganic nitrogen; TSS: total suspended solid.

\subsection{Analytical Methods}

The dissolved oxygen (DO) and $\mathrm{pH}$ were measured by $\mathrm{DO}$ and $\mathrm{pH}$ meters $(\mathrm{HACH}$, HQ40d). The concentrations of COD, soluble chemical oxygen demand (SCOD), ammonia, nitrate, nitrite, mixed liquor volatile suspended solid (MLVSS), and TSS were measured using the standard methods [17]. Biofilm thickness was photographed and calculated as a distance from the surface of the carrier to the top of the biofilm by a fluorescent Inverted microscope (Olympus, IX71). Biomass on the carriers was measured after scraping the biomass off by cotton swabs [18]. Statistical analyses (paired t-test) were performed using GraphPad Prism 8.0 software to identify the differences between each data sample, and detachment rates with a p-value less than 0.05 indicating significance. Moreover, high-throughput sequencing was used to explore the variation of the bacterial community 
collected on day 79 (Major Bio). Primers set of 338F and 806R were used to amplify V3 V4 regions [19].

The nutrient removal efficiency (RE) was calculated by the equation:

$$
R E=\frac{\left(C_{I}-C_{E}\right)}{C_{I}} \times 100 \%
$$

where $C_{I}$ and $C_{E}$ are the nutrient concentration $(\mathrm{mg} / \mathrm{L})$ in the influents and effluents of the bioreactor or section, respectively. The nutrient removal loading (RL) of the bioreactor and different sections were calculated by the following equation:

$$
\mathrm{RL}=\frac{\mathrm{Q} \times\left(\mathrm{C}_{\mathrm{I}}-\mathrm{C}_{\mathrm{E}}\right)}{\mathrm{V}}
$$

where $\mathrm{Q}$ is the influent flow $\left(\mathrm{m}^{3} /\right.$ day) and $\mathrm{V}$ is the volume.

\section{Results and Discussion}

\subsection{Nutrients Removal Performance}

\subsubsection{Overall Performance of HPBR}

The concentrations of COD, ammonia, TIN, and TSS in the influents and effluents of the long-term operation were tested to evaluate the overall wastewater treatment performance of HPBR. Because the water source is WWTP, the water quality of the influents fluctuated greatly during the long-term operation. As depicted in Figure 2 the COD concentrations fluctuated in the influents, but a reasonably stable level was achieved after treatment. A similar trend was observed in ammonia removal performance where concentration in the effluents was relatively low and stable compared to the influents $(40.3 \pm 13.1 \mathrm{mg} / \mathrm{L})$. Meanwhile, the ammonia removal loading (ARL) was fixed around $0.26 \pm 0.10 \mathrm{~kg} / \mathrm{m}^{3} / \mathrm{d}$ regardless of fluctuated influent ammonia loading (AL) and the decreasing water temperature during long-term operation, which confirms a stable removal behavior of the HPBR. It is worth mentioning that the TSS, as one of the most significant parameters in rural wastewater treatment, the concentrations of TSS are quite low, only around $22.9 \pm 14.6 \mathrm{mg} / \mathrm{L}$ in the effluents.

Unlike the wastewater in cities, rural wastewater has the characteristics of high organic matter proportions and great variations of influent water quality. As from Figure S1, the effect of different influencing factors was investigated in the long-term operation. It is obvious that the removal efficiency of nutrients was not affected significantly by all parameters. Specifically, the $\mathrm{pH}$ has a negative impact on the stability of the bioreactor while other parameters such as $\mathrm{C} / \mathrm{N}$ ratio, temperature, and $\mathrm{DO}$ were positive influencing factors. However, these impacts were negligible during the change of all influencing parameters indicating that the bioreactor in this research was reliable in treating complicated wastewater.

\subsubsection{Role of Different Treatment Sections}

For HPBR, one of the advantages is the design of two different sections. The aeration section, with aerator provided dissolved oxygen, functioned as an aerobic zone in the HPBR. While the filtration section, with no oxygen supply, was used to be a post endogenous denitrification zone and filter. More importantly, the setup of FS can remove most of the shedding biomass from AS which ensures the stability of the effluents. Unlike other HPBR systems, the bioreactor in this study can function independently with no subsequent facilities. This favors its application in rural areas.

For these two sections, the different environments made the carriers inside vary considerably in appearance which can be characterized by the biofilm thickness and biomass on the carriers. As shown in Figure 3, the average biofilm thickness on the carriers in AS and FS were 338.6 and $149.6 \mu \mathrm{m}$, respectively. Comparing with carriers in FS, the average biofilm thickness in AS is $126.26 \%$ higher as the carriers in AS was wrapped with a fluffy biofilm in the outer layer. Meanwhile, the average biomass on the carriers in AS and 
FS were $18.433 \pm 1.843 \mathrm{gMLVSS} / \mathrm{m}^{2}$ and $15.899 \pm 1.382 \mathrm{gMLVSS} / \mathrm{m}^{2}$, respectively. This may be due to the fact that most of the removed nutrients were consumed in the AS, which significantly increased the growth of biomass onto carriers in AS.

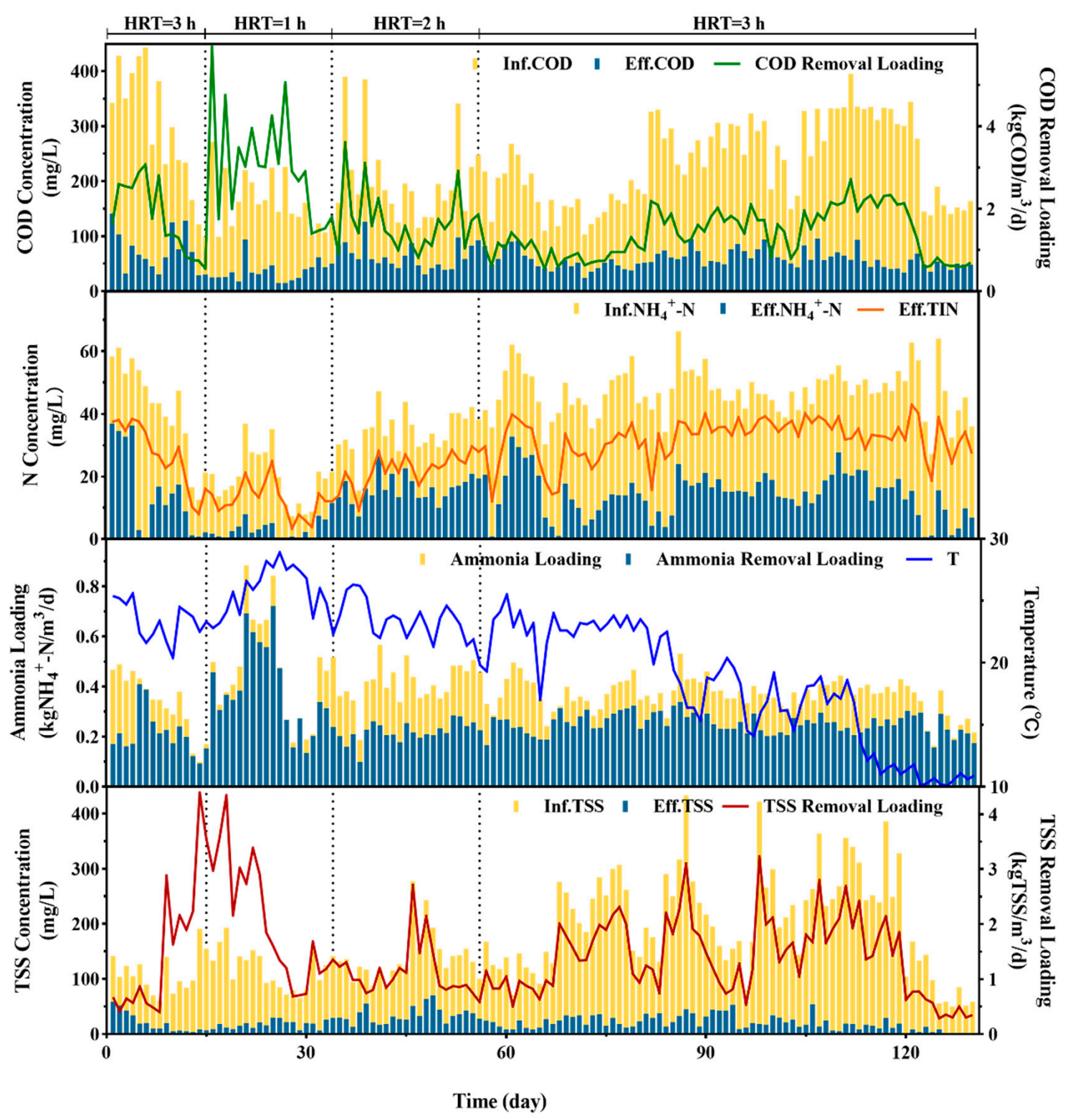

Figure 2. Nutrients removal performance in the bioreactor.

The concentrations of ammonia, TIN, COD, and TSS in influent and two sections' effluents and their removal loading and removal percentages were given in Table 2. It is calculated that most of the nutrients were removed in AS, specifically, $93.83 \%$ of the removed ammonia, $70.65 \%$ of the removed TIN, $87.93 \%$ of the removed COD, and $85.01 \%$ of the removed TSS occurred in AS. That is to say, as stated previously, the organic matter oxidization and denitrification reactions occurred sufficiently in AS, with the COD and ammonia removal loading reaching $6.03 \pm 3.59 \mathrm{~g} / \mathrm{m}^{2} / \mathrm{d}$ and $0.97 \pm 0.35 \mathrm{~g} / \mathrm{m}^{2} / \mathrm{d}$ in AS, respectively. On the other hand, FS functioned for further enhanced purification and denitrification. The average TSS concentration decreased to $22.9 \pm 14.6 \mathrm{mg} / \mathrm{L}$ from $44.6 \pm 25.4 \mathrm{mg} / \mathrm{L}$ (effluent of AS), and $4.3 \mathrm{mg} / \mathrm{L}$ more of TIN was further denitrified in the FS. This setup of the two different sections guaranteed the water quality of the effluent in terms of ammonia, TIN, COD, and TSS, which are the main nutrients in the 
rural wastewater. Specifically, the filtration effect in FS removed the excessive TSS in the wastewater, ensured the TSS concentration in the effluents lower than $25 \mathrm{mg} / \mathrm{L}$ because higher TSS concentrations will have direct negative impacts on people's feelings in rural areas (Figure S2).
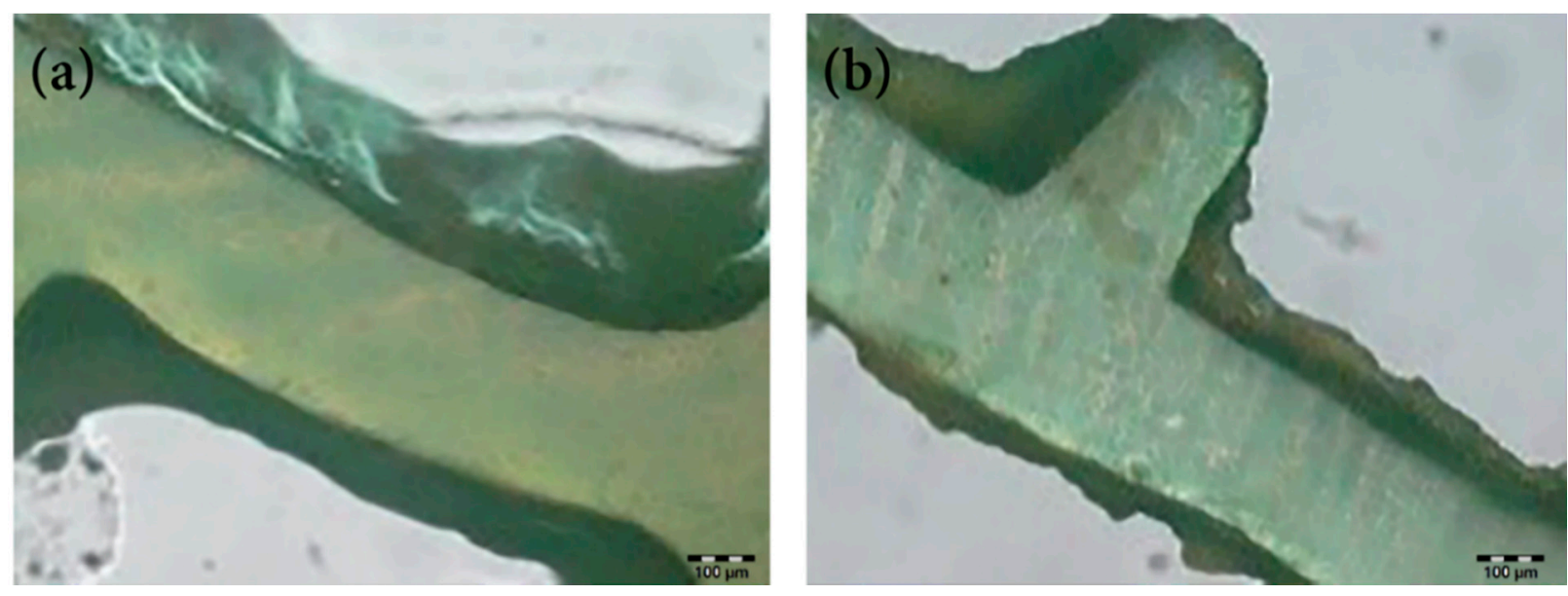

Figure 3. Digital photos of biofilm on the carriers in (a) aeration section and (b) filtration section.

Table 2. Nutrients concentrations and removal loading in influent and different sections.

\begin{tabular}{|c|c|c|c|c|c|c|c|}
\hline \multirow[b]{2}{*}{ Nutrient } & \multirow{2}{*}{$\begin{array}{c}\text { Influent } \\
\text { (mg/L) }\end{array}$} & \multicolumn{3}{|c|}{ AS } & \multicolumn{3}{|c|}{ FS } \\
\hline & & $\begin{array}{c}\text { Effluent } \\
\text { (mg/L) }\end{array}$ & $\begin{array}{l}\text { RE } \\
(\%)\end{array}$ & $\underset{\left(\mathrm{g} / \mathrm{m}^{2} / \mathrm{d}\right)}{\mathrm{RL}}$ & $\begin{array}{l}\text { Effluent } \\
\text { (mg/L) }\end{array}$ & $\begin{array}{l}\mathrm{RE} \\
(\%)\end{array}$ & $\begin{array}{c}\text { RL } \\
\left(\mathrm{g} / \mathrm{m}^{2} / \mathrm{d}\right)\end{array}$ \\
\hline COD & $226.0 \pm 84.9$ & $78.0 \pm 31.7$ & $65.49 \%$ & $6.03 \pm 3.59$ & $57.6 \pm 23.5$ & $26.15 \%$ & $0.78 \pm 0.71$ \\
\hline Ammonia & $40.3 \pm 13.1$ & $14.8 \pm 8.7$ & $63.28 \%$ & $0.97 \pm 0.35$ & $13.1 \pm 8.4$ & $11.49 \%$ & $0.07 \pm 0.11$ \\
\hline TIN & $41.6 \pm 13.0$ & $31.2 \pm 10.5$ & $25.00 \%$ & $0.39 \pm 0.20$ & $26.9 \pm 9.7$ & $13.78 \%$ & $0.19 \pm 0.17$ \\
\hline TSS & $167.8 \pm 83.5$ & $44.6 \pm 25.4$ & $73.42 \%$ & $5.08 \pm 3.25$ & $22.9 \pm 14.6$ & $48.65 \%$ & $0.80 \pm 0.66$ \\
\hline
\end{tabular}

COD: chemical oxygen demand; TIN: total inorganic; TSS: total suspended solid; RE: removal efficiency; RL: removal loading.

\subsection{Mechanism of Sufficient Nutrients Removal Efficiency}

In this bioreactor, stable nutrient removal ability was achieved in real wastewater treatment with fluctuated nutrient concentrations in the influents. Meanwhile, the nutrient removal capability was higher than other reported reactors. Table 3 summarized and compared the nutrients removal loadings in different bioreactors reported in other literatures. It is obviously noted that a dominated COD removal loading was achieved in AS from HPBR comparing with other reactors. In addition, ammonia removal loading was considerably higher than the others. In summary, $3.04 \pm 1.81 \mathrm{~kg} \mathrm{COD} / \mathrm{m}^{3} / \mathrm{d}$, $0.49 \pm 0.18 \mathrm{~kg} \mathrm{NH}{ }^{+}-\mathrm{N} / \mathrm{m}^{3} / \mathrm{d}$, and $2.56 \pm 1.64 \mathrm{~kg}$ TSS $/ \mathrm{m}^{3} / \mathrm{d}$ were achieved in the AS of HPBR. This may be due to the high packing ratio in the HPBR: The amount of the carriers per volume and the amount of the biomass per carrier are considerably higher than other bioreactors, this created a more efficient bioprocess in treating rural wastewater. The high removal loading means that this HPBR can remove more COD and ammonia than other bioreactors with same operation time. However, as stated in Section 2.2, the high packing ratio of the HPBR caused a situation that the carriers cannot fluidize inside the bioreactor. As a result of that, the biofilm on the carriers grew out-of-control as operation continued. The substrate transfer rate, meanwhile, will be retarded due to limitations by the fast-growing biofilm. Similar overgrowth of biofilm situation was also observed by other research where researchers have to reduce the loadings of the ammonia and COD to couple with the carrier clogging issue [13]. However, the clogging problem was just delayed but not solved. Hence, in order to solve the clogging problem and facilitate the biofilm renewal on the carriers in HPBR, an innovative cycle cleaning process was conducted daily. During 
the cycle cleaning process, the carriers can fluidize inside the HPBR, which function as a moving bed biofilm reactor (MBBR), the surplus biofilm on the carriers will be removed sufficiently due to the shear force caused by larger aeration and hydraulic cycle.

In order to investigate the importance of the cycle cleaning process on nutrients removal in HPBR, the average nitrification rate, SCOD removal rate, and biofilm thickness before and after the cycle cleaning process were analyzed in batch tests and given in Figure 4 . The cycle cleaning process significantly increased the average nitrification rate from $0.82 \mathrm{gN} / \mathrm{m}^{2} / \mathrm{d}$ to $1.01 \mathrm{gN} / \mathrm{m}^{2} / \mathrm{d}$ and the SCOD removal rate from $5.70 \mathrm{gSCOD} / \mathrm{m}^{2} / \mathrm{d}$ to $7.08 \mathrm{gSCOD} / \mathrm{m}^{2} / \mathrm{d}$. The significance of higher nitrification and SCOD oxidizing rate was confirmed after cycle cleaning process by paired t-test with $p<0.05$. This result was in accordance with our assumption that the shedding of the surplus biofilm is not only beneficial to relieving clogging problem but also improve the substrate transfer rate among the cross section on the carriers. Cui found that the backwash significantly compromised the activities of the functional microorganisms in the bioreactor [20]. However, in this study, the system functioned as a fixed bed bioreactor under normal operation status, which means that the shear force to the attached biofilm was negligible. The biomass on the carriers, with no external force, will grow without control. By cycle cleaning, the outer layer of the biofilm, which has an incompact attachment to the carriers, was shed out and eventually discharged with the cleaning effluent. This step facilitated the update of the biofilm, exposed the inner functional biofilm, and improved the substance transfer efficiency, which led to a better degradation rate. As shown in Figure 4c,d, before the cycle cleaning process, the average thickness of the attached biofilm was $243.3 \mu \mathrm{m}$ and it decreased to $159.8 \mu \mathrm{m}$ after cleaning. In addition, the biofilm before cleaning was unconsolidated on the carriers while the cleaning process washed out the surplus biofilm and left the compact biofilm on the carriers. Therefore, a regular cycle cleaning process may be an effective solution to the carrier clogging problem in this highly packed bioreactor. To further explore the contribution and mechanism of cycle cleaning process in nitrogen and organic matter removal inside the HPBR, a typical cyclic test was performed. Figure 5 depicted the removal rate of nitrogen and organic matter before and after the cycle cleaning process. The SCOD concentration after the cleaning process declined dramatically in the first $0.5 \mathrm{~h}$ followed by a plateau while a relatively smooth degradation curve was observed before the cleaning process. A similar tendency was also observed in ammonia degradation where a significantly faster removal rate occurred after cycle cleaning process. These results confirmed the significance of the cycle cleaning process in HPBR, which shed out the surplus biofilm, facilitated the substrate transfer rate between the inner layer of the carrier and aqueous solution, and eventually improved nutrients removal rate in the HPBR.

In order to gain a better understanding of the nutrient's removal mechanism in HPBR before and after cycle cleaning, microbial communities of raw sludge and cultivated biofilm (before and after cycle cleaning) were investigated by high-throughput sequencing. First, the compositions of key bacterial at phylum level were analyzed (Figure 6). The dominant Proteobacteria was observed in all samples, which accounted for around $40 \%$ of the community. Proteobacteria is considered as one of the most common nitrogen removing related microbes [21], and its stable presence in HPBR ensured the stable removal efficiency of ammonia. In addition, Bacteroidota, which played an important role in organic matter degradation [22], increased from $6.11 \%$ (raw sludge) to $16.49 \%$ (before cleaning) and $18.73 \%$ (after cleaning). This might be one of the important reasons for the efficient organic matter removal performance in HPBR. The proportion of Nitrospirota (also known as Nitrospirae), which is related to nitrite oxidation process [23], increased from $0.03 \%$ (raw sludge) to $1.17 \%$ (before cleaning), then decreased to $0.35 \%$ (after cleaning). The decreased proportion of Nitrospirota after cleaning led to a compromised nitrite removal problem, which was in accordance with the typical cyclic test (Figure 5) where a significant nitrite accumulation was observed after cleaning. However, the recovery of the Nitrospirota in HPBR is rapid because nitrite is all oxidized at $2 \mathrm{~h}$ after cycle cleaning. 

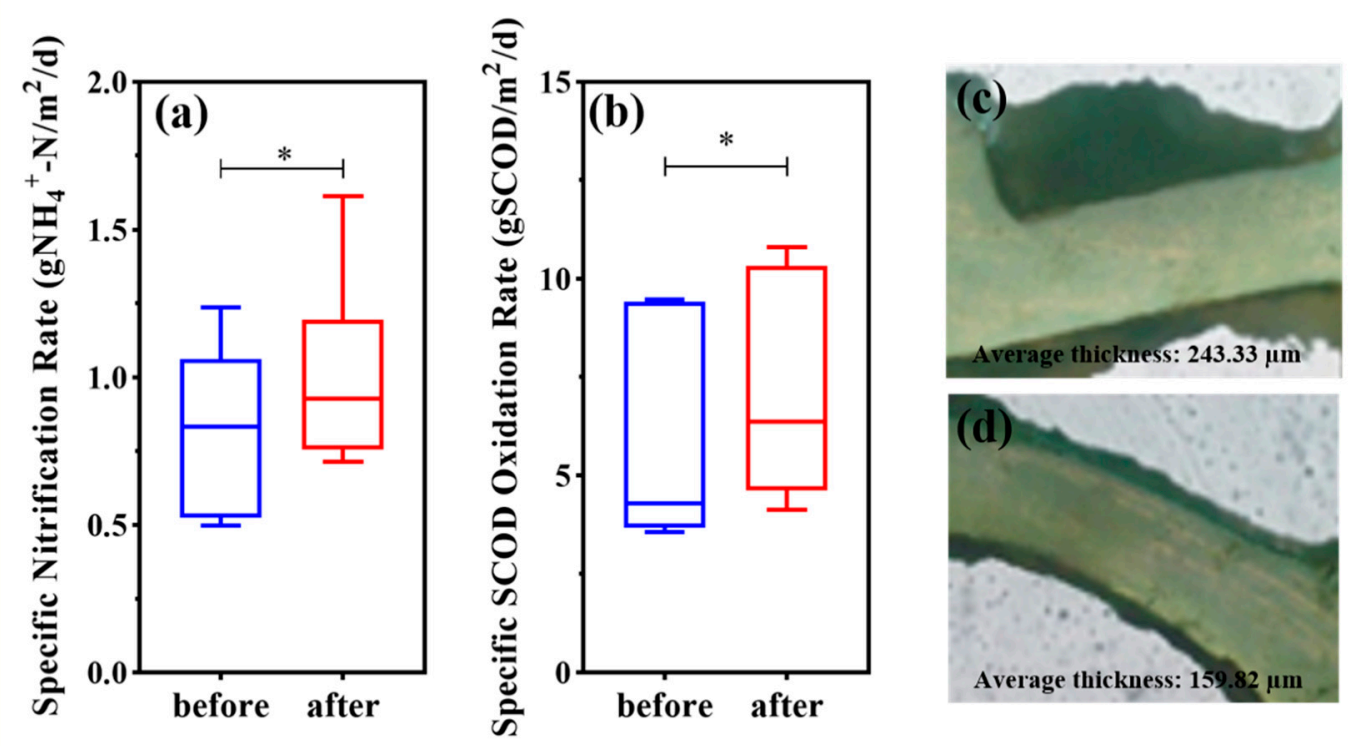

Figure 4. The average nitrification rate before and after cycle cleaning process $(p=0.037, n=7)(\mathbf{a})$, the average soluble chemical oxygen demand (SCOD) removal rate before and after cycle cleaning process $(p=0.044, n=7)(\mathbf{b})$, digital photo of biofilm before cycle cleaning (c), and digital photo of biofilm after cycle cleaning process (d).

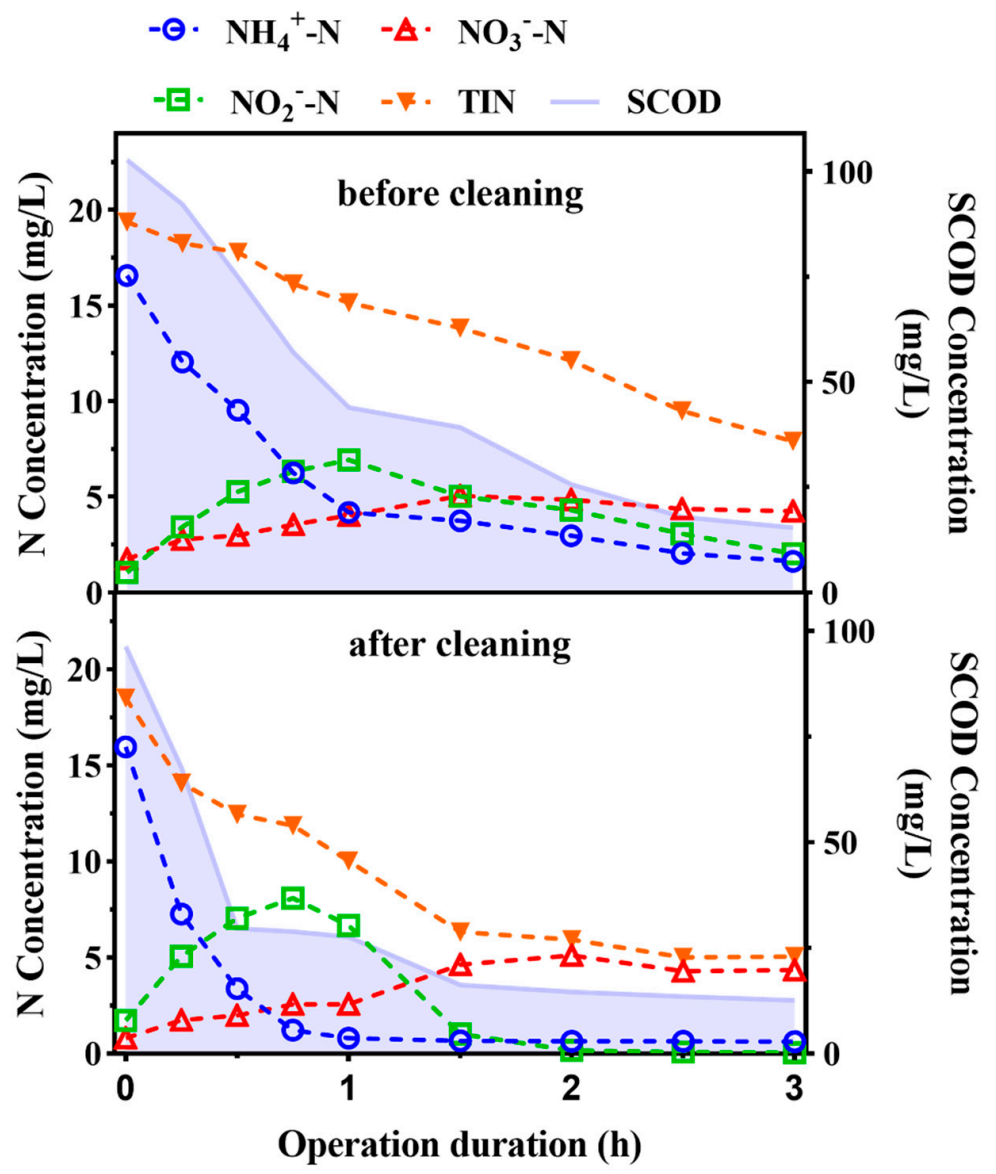

Figure 5. A typical cyclic test for degradation of SCOD and nitrogen before and after cycle cleaning process. 


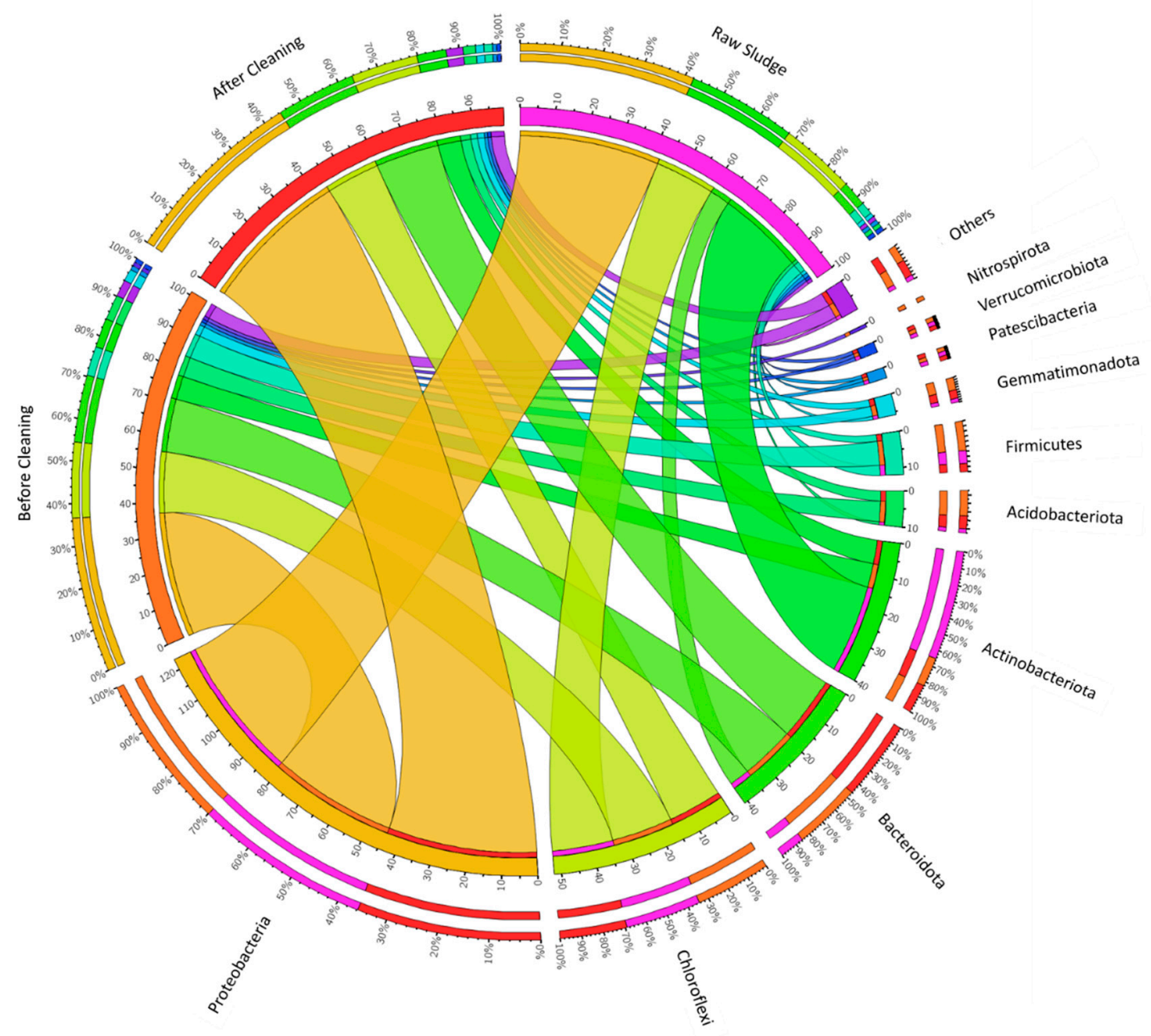

Figure 6. Microbial community profiles of three biofilm samples at phylum level. The coordinate scale refers to the relative abundance of the microbial distribution in the samples (\%).

The relative abundance of nitrogen removal functional bacterial communities at genus level of biofilm before cleaning and after cleaning is shown in Figure 7. The abundance of nitrite-oxidizing bacteria, Nitrospira, significantly decreased after cycle cleaning process like the Nitrospirota phylum [24]. The same tendency was observed in autotrophic nitrifiers and heterotrophic denitrifiers. Chitinophagaceae and Nitrosomonas are two main autotrophic nitrifiers that decreased after cleaning $[25,26]$. However, the decrease of the heterotrophic denitrifiers was not significant, and the total relative abundance dropped to $12.25 \%$. The stable presence of these microorganisms ensured a stable simultaneous nitrification and denitrification (SND) process. For the microorganisms capable of heterotrophic nitrification and aerobic denitrification, the total relative abundance increased significantly from $8.13 \%$ to $12.93 \%$. Heterotrophic nitrification and aerobic denitrification via different enzymes also contributed to the SND process in HPBR, especially when traditional nitrification was slightly compromised by the cycle cleaning process [27-29]. The stable presence of these microbes could be due to the anoxic zone in the inner layer of the biofilm caused by the thick biofilm. A similar situation was observed by Zhang, where denitrification occurred due to the limited DO diffusion through the biofilm and the consequent anoxic environment inside the biofilm [30,31]. The microbial community analysis ensured the nitrogen removal capacity of the HPBR in treating rural wastewater. 


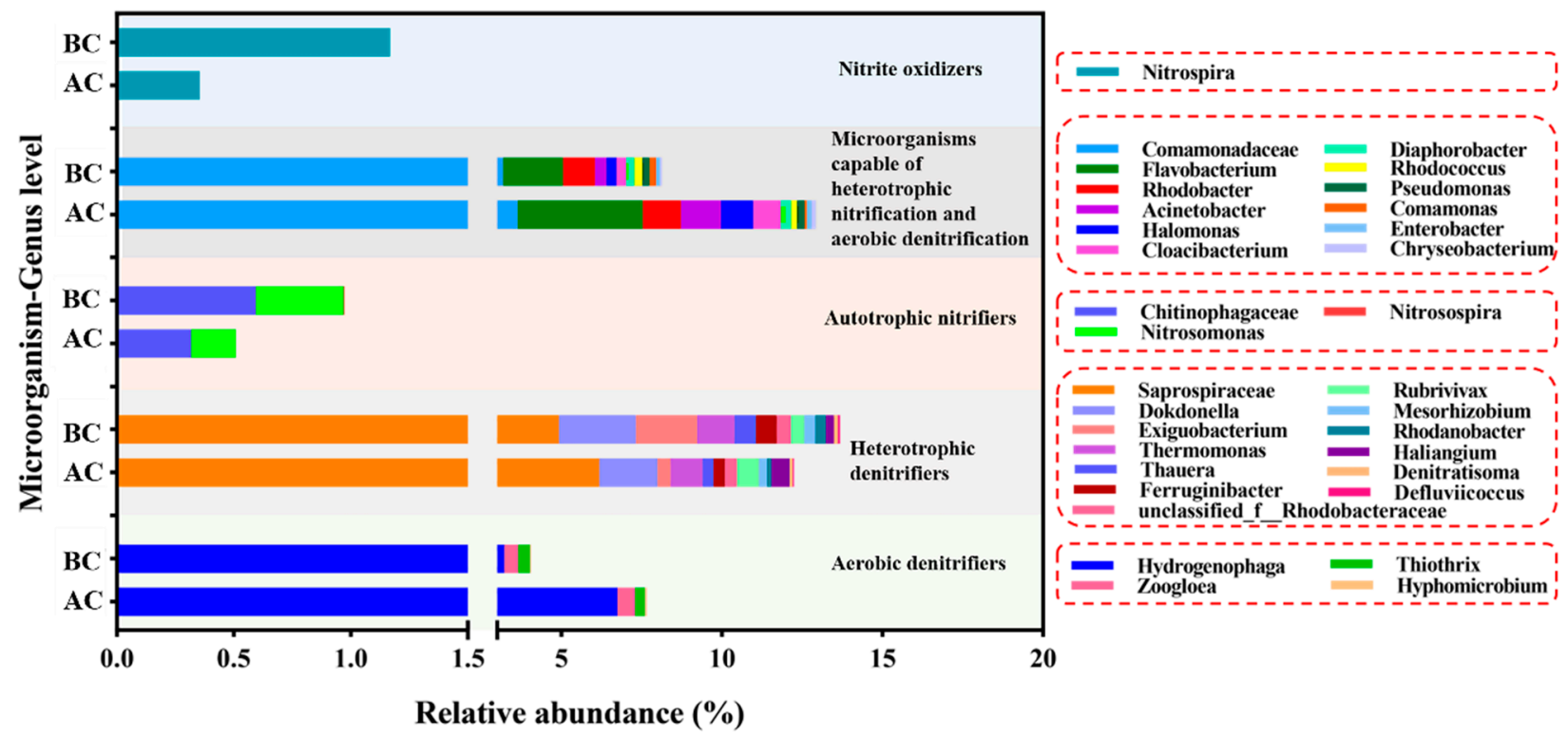

Figure 7. Relative abundance of nitrogen removal functional bacterial communities at genus level of biofilm before cleaning (BC) and after cleaning (AC).

\subsection{Implications for Rural Wastewater Treatment Systems}

Currently, the most significant concern of the rural wastewater treatment is to develop an integrated and intensive equipment. For all the technologies with competent removal capacity nowadays, most of them are not applicable due to high demand of professional maintenance and large floor space. Few technologies were designed and applied for real rural wastewater treatment. In this research, to overcome the realistic issues in rural wastewater treatment, a two-stage highly packed bioreactor was invented and tested under domestic wastewater. Unlike previous researches, a filtration section is added in this study, based on the data given previously, two-stage HPBR is more efficient in treating rural wastewater in terms of nutrient removal loadings and stability. As the water quality of the influent wastewater fluctuated in a large range, the reactor showed stable removal performance. Meanwhile, functioning as compact and facile equipment for rural wastewater treatment, the technology should be cost-efficient otherwise the application would be impossible. In this study, the investment of the HPBR is distinctly lower than other reported technologies due to no expensive components involved. Hence, the design of HPBR appears most promising in this field. Moreover, comparing with other technologies, the bioreactor was operated easily with no complex procedures inside, which means that professional maintenance is unnecessary during daily operation. This concept appears to offer advantages for rural wastewater treatment in developing countries such as China, where a very low-cost, low-maintenance, and efficient process is essential. In future real applications, several optimizations could be made. For example, the volume of the FS could be reduced to shorten the HRT, the operation mode could be switched to have better effluent water quality, and eventually maximize the removal capacity of HPBR. 
Table 3. Comparison of nutrients removal loading with other bioreactors.

\begin{tabular}{|c|c|c|c|c|c|c|c|c|c|c|c|}
\hline Reactor & Feed & $\begin{array}{c}\text { DO } \\
(\mathrm{mg} / \mathrm{L})\end{array}$ & $\mathrm{T}\left({ }^{\circ} \mathrm{C}\right)$ & $\begin{array}{c}\text { COD Influent } \\
\text { Concentration } \\
(\mathrm{mg} / \mathrm{L})\end{array}$ & $\begin{array}{c}\text { Ammonia } \\
\text { Influent } \\
\text { Concentration } \\
(\mathrm{mg} / \mathrm{L})\end{array}$ & $\begin{array}{c}\text { TSS Influent } \\
\text { Concentration } \\
(\mathrm{mg} / \mathrm{L})\end{array}$ & $\begin{array}{c}\text { COD } \\
\text { Removal } \\
\text { Loading }^{\mathrm{b}} \\
\left(\mathrm{kg} / \mathrm{m}^{3} / \mathrm{d}\right)\end{array}$ & $\begin{array}{c}\text { Ammonia } \\
\text { Removal } \\
\text { Loading }^{\mathrm{b}} \\
\left(\mathrm{kg} / \mathrm{m}^{3} / \mathrm{d}\right)\end{array}$ & $\begin{array}{l}\text { TSS Removal } \\
\text { Loading b } \\
\left.\text { (kg/m }{ }^{3} / \mathrm{d}\right)\end{array}$ & $\begin{array}{l}\text { Cycle } \\
\text { Cleaning } \\
\text { Process }\end{array}$ & Reference \\
\hline HPBR & $\begin{array}{c}\text { Domestic } \\
\text { wastewater }\end{array}$ & $6.7 \pm 1.2$ & $20.6 \pm 4.9$ & $231.5 \pm 94.8$ & $40.3 \pm 13.1$ & $167.8 \pm 83.5$ & $3.04 \pm 1.81$ & $0.49 \pm 0.18$ & $2.56 \pm 1.64$ & Yes & This study \\
\hline MBBR & $\begin{array}{c}\text { Domestic } \\
\text { wastewater }\end{array}$ & $7.4-8.8$ & 20 & $63.27-71.04$ & $58-65.78$ & - & $0.32^{\mathrm{a}}$ & $0.09^{\mathrm{a}}$ & - & No & [13] \\
\hline MBBR & Diluted water & - & - & $99.8 \pm 61.3$ & $47.4 \pm 8.6$ & - & - & $0.04^{\mathrm{a}}$ & - & No & [31] \\
\hline $\begin{array}{l}\text { ANF/ms-wdRBCs } \\
\text { coupling device }\end{array}$ & $\begin{array}{c}\text { Synthetic } \\
\text { wastewater }\end{array}$ & - & $15-32$ & $110.26 \pm 5.96$ & $24.98 \pm 0.95$ & - & $0.29^{\mathrm{a}}$ & $0.07^{\mathrm{a}}$ & - & No & [12] \\
\hline $\begin{array}{l}\text { vertical flow trickling } \\
\text { filter (VFTF) }\end{array}$ & $\begin{array}{l}\text { Synthetic } \\
\text { wastewater }\end{array}$ & - & - & $255.20 \pm 65.12$ & $48.91 \pm 7.93$ & - & $0.81^{\mathrm{a}}$ & $0.03^{\mathrm{a}}$ & - & No & [14] \\
\hline
\end{tabular}

${ }^{a}$ calculate from provided data; ${ }^{\mathrm{b}}$ removal loading of AS. 


\section{Conclusions}

In this study, sufficient rural wastewater treatment was conducted in a two-stage highly packed biofilm reactor. Lower concentrations of COD, TSS, and nitrogen were achieved in the effluents of HPBR, which successfully met the current requirements for rural wastewater treatment. The high packing ratio of the bioreactor was not only beneficial to the sufficient treatment of rural wastewater with fewer occupations but could also promote the growth of the biofilm on the carriers, which facilitates the denitrification progress. An innovative cycle cleaning process was conducted daily which successfully overcome the carrier clogging problem and improve the substrate transfer rate. Moreover, the microbial community results showed that the SND process governed the nitrogen removal in HPBR. These findings in this study highlight the HPBR as a facile and efficient rural wastewater treatment technology to achieve high and stable removal loadings at low costs, demonstrating that this bioreactor is highly viable for real applications in treating wastewater in rural areas.

Supplementary Materials: The following are available online at https:/ /www.mdpi.com/2073-444 1/13/3/369/s1, Figure S1: The effect of different influencing factors in influents, Figure S2: Digital pictures of the influent (left) and effluent (right).

Author Contributions: Y.L. (Yanan Luan): Methodology, investigation, data curation, formal analysis, writing—original draft. C.Q.: methodology, investigation; Y.L. (Yaoxian Li): methodology, investigation; W.K.: methodology, investigation; J.Z.: conceptualization, writing - review and editing; Z.L.: conceptualization, supervision; X.B.: conceptualization, supervision, project administration. All authors have read and agreed to the published version of the manuscript.

Funding: This study was funded by National Major Science and Technology Program for Water Pollution Control and Treatment (No. 2017ZX07101-002-005) and Water JPI "Closing the Water Cycle Gap with Harmonised Actions for Sustainable Management of Water Resources" (WJPI 385741).

Institutional Review Board Statement: Not applicable.

Informed Consent Statement: Not applicable.

Data Availability Statement: The data used to support this study are available from the corresponding author upon request.

Acknowledgments: The authors would like to thank the editors and anonymous reviewers for editing and review.

Conflicts of Interest: The authors declare no conflict of interest.

\section{References}

1. Li, Y.; Guo, J.; Li, H.; Song, Y.; Chen, Z.; Lu, C.; Han, Y.; Hou, Y. Effect of dissolved oxygen on simultaneous removal of ammonia, nitrate and phosphorus via biological aerated filter with sulfur and pyrite as composite fillers. Bioresour. Technol. 2020, $296,122340$. [CrossRef]

2. Rott, E.; Steinmetz, H.; Metzger, J.W. Organophosphonates: A review on environmental relevance, biodegradability and removal in wastewater treatment plants. Sci. Total Environ. 2018, 615, 1176-1191. [CrossRef] [PubMed]

3. Yin, Y.; Xu, G.; Li, L.; Xu, Y.; Zhang, Y.; Liu, C.; Zhang, Z. Fabrication of Ceramsite Adsorbent from Industrial Wastes for the Removal of Phosphorus from Aqueous Solutions. J. Chem. 2020, 2020, 1-13. [CrossRef]

4. Nie, E.; Wang, D.; Yang, M.; Luo, X.; Fang, C.; Yang, X.; Su, D.; Zhou, L.; Zheng, Z. Tower bio-vermifilter system for rural wastewater treatment: Bench-scale, pilot-scale, and engineering applications. Int. J. Environ. Sci. Technol. 2015, 12, 1053-1064. [CrossRef]

5. Wang, Q.; He, J. Complete nitrogen removal via simultaneous nitrification and denitrification by a novel phosphate accumulating Thauera sp. strain. Water Res. 2020, 185, 116300. [CrossRef]

6. Loupasaki, E.; Diamadopoulos, E. Attached growth systems for wastewater treatment in small and rural communities: A review. J. Chem. Technol. Biotechnol. 2013, 88, 190-204. [CrossRef]

7. Chen, F.; Yao, Q. The Development of Rural Domestic Wastewater Treatment in China. Adv. Mater. Res. 2014, 1073-1076, 829-832. [CrossRef]

8. Singh, N.K.; Kazmi, A.A.; Starkl, M. A review on full-scale decentralized wastewater treatment systems: Techno-economical approach. Water Sci. Technol. 2015, 71, 468-478. [CrossRef] 
9. Chen, G.; Huang, J.; Fang, Y.; Zhao, Y.; Tian, X.; Jin, Y.; Zhao, H. Microbial community succession and pollutants removal of a novel carriers enhanced duckweed treatment system for rural wastewater in Dianchi Lake basin. Bioresour. Technol. 2019, 276, 8-17. [CrossRef]

10. Zou, J.; Guo, X.; Han, Y.; Liu, J.; Liang, H. Study of a novel vertical flow constructed wetland system with drop aeration for rural wastewater treatment. Water. Air. Soil Pollut. 2012, 223, 889-900. [CrossRef]

11. Guo, X.; Liu, Z.; Chen, M.; Liu, J.; Yang, M. Decentralized wastewater treatment technologies and management in Chinese villages. Front. Environ. Sci. Eng. 2014, 8, 929-936. [CrossRef]

12. Zha, X.; Ma, J.; Lu, X. Performance of a coupling device combined energy-efficient rotating biological contactors with anoxic filter for low-strength rural wastewater treatment. J. Clean. Prod. 2018, 196, 1106-1115. [CrossRef]

13. Ashkanani, A.; Almomani, F.; Khraisheh, M.; Bhosale, R.; Tawalbeh, M.; AlJaml, K. Bio-carrier and operating temperature effect on ammonia removal from secondary wastewater effluents using moving bed biofilm reactor (MBBR). Sci. Total Environ. 2019, 693, 133425. [CrossRef] [PubMed]

14. Zhang, Y.; Cheng, Y.; Yang, C.; Luo, W.; Zeng, G.; Lu, L. Performance of system consisting of vertical flow trickling filter and horizontal flow multi-soil-layering reactor for treatment of rural wastewater. Bioresour. Technol. 2015, 193, 424-432. [CrossRef]

15. Rathnaweera, S.S.; Rusten, B.; Korczyk, K.; Helland, B.; Rismyhr, E. Novel biofilm reactor for denitrification of municipal wastewater. Water Sci. Technol. 2018, 78, 1566-1575. [CrossRef]

16. Rathnaweera, S.S.; Rusten, B.; Manamperuma, L.D.; Wang, S.; Helland, B. Innovative, compact and energy-efficient biofilm process for nutrient removal from wastewater. Water Sci. Technol. 2020, 81, 1941-1950. [CrossRef] [PubMed]

17. Association, A.P.H.; Association, A.W.W.; Federation, W.P.C.; Federation, W.E. Standard Methods for the Examination of Water and Wastewater; American Public Health Association: Washington, DC, USA, 1915; Volume 2, ISBN 8755-3546.

18. Kowalski, M.S.; Devlin, T.R.; di Biase, A.; Oleszkiewicz, J.A. Effective nitrogen removal in a two-stage partial nitritation-anammox reactor treating municipal wastewater-Piloting PN-MBBR/AMX-IFAS configuration. Bioresour. Technol. 2019, $289,121742$. [CrossRef]

19. Zhou, H.; Xu, G. Integrated effects of temperature and COD/N on an up-flow anaerobic filter-biological aerated filter: Performance, biofilm characteristics and microbial community. Bioresour. Technol. 2019, 293, 122004. [CrossRef] [PubMed]

20. Cui, B.; Yang, Q.; Zhang, Y.; Liu, X.; Wu, W.; Li, J. Improving nitrogen removal in biological aeration filter for domestic sewage treatment via adjusting microbial community structure. Bioresour. Technol. 2019, 293, 122006. [CrossRef]

21. Wang, L.; Li, B.; Li, Y.; Wang, J. Enhanced biological nitrogen removal under low dissolved oxygen in an anaerobic-anoxic-oxic system: Kinetics, stoichiometry and microbial community. Chemosphere 2021, 263, 128184. [CrossRef]

22. Wu, L.; Yang, Y.; Guo, W.; Huang, W.; Peng, Z.; Zhang, Z.; Zou, M.; Luo, J. Deterioration of biological pollutants removal induced by linear alkylbenzene sulphonates in sequencing batch reactors: Insight of sludge characteristics, microbial community and metabolic activity. Bioresour. Technol. 2020, 315, 123843. [CrossRef]

23. Young, B.; Delatolla, R.; Kennedy, K.; Laflamme, E.; Stintzi, A. Low temperature MBBR nitrification: Microbiome analysis. Water Res. 2017, 111, 224-233. [CrossRef] [PubMed]

24. Zhang, J.; Zhang, Q.; Miao, Y.; Sun, Y.; Chen, J.; Peng, Y. Stable and efficient partial nitritation granular sludge reactor treating domestic sewage at low temperature. Bioresour. Technol. 2018, 270, 746-750. [CrossRef] [PubMed]

25. De Celis, M.; Belda, I.; Ortiz-Álvarez, R.; Arregui, L.; Marquina, D.; Serrano, S.; Santos, A. Tuning up microbiome analysis to monitor WWTPs' biological reactors functioning. Sci. Rep. 2020, 10, 1-8. [CrossRef] [PubMed]

26. Deng, S.; Li, D.; Yang, X.; Zhu, S.; Li, J. Process of nitrogen transformation and microbial community structure in the Fe(0)-carbonbased bio-carrier filled in biological aerated filter. Environ. Sci. Pollut. Res. 2016, 23, 6621-6630. [CrossRef] [PubMed]

27. Liu, X.; Zhu, H. Treatment of Low C/N Ratio Wastewater by a Carbon Cloth Bipolar Plate Multicompartment Electroenhanced Bioreactor (CBM-EEB). ACS Omega 2020, 5, 27823-27832. [CrossRef] [PubMed]

28. Zhang, J.; Miao, Y.; Zhang, Q.; Sun, Y.; Wu, L.; Peng, Y. Mechanism of stable sewage nitrogen removal in a partial nitrificationanammox biofilm system at low temperatures: Microbial community and EPS analysis. Bioresour. Technol. 2020, 297, 122459. [CrossRef]

29. Zhang, L.; Liu, J.; Liu, C.; Zhang, J.; Yang, J. Performance of a fixed-bed biofilm reactor with Microbubble aeration in aerobic wastewater treatment. Water Sci. Technol. 2016, 74, 138-146. [CrossRef]

30. Yang, S.; Yang, F. Nitrogen removal via short-cut simultaneous nitrification and denitrification in an intermittently aerated moving bed membrane bioreactor. J. Hazard. Mater. 2011, 195, 318-323. [CrossRef]

31. Kouba, V.; Widiayuningrum, P.; Chovancova, L.; Jenicek, P.; Bartacek, J. Applicability of one-stage partial nitritation and anammox in MBBR for anaerobically pre-treated municipal wastewater. J. Ind. Microbiol. Biotechnol. 2016, 43, 965-975. [CrossRef] 